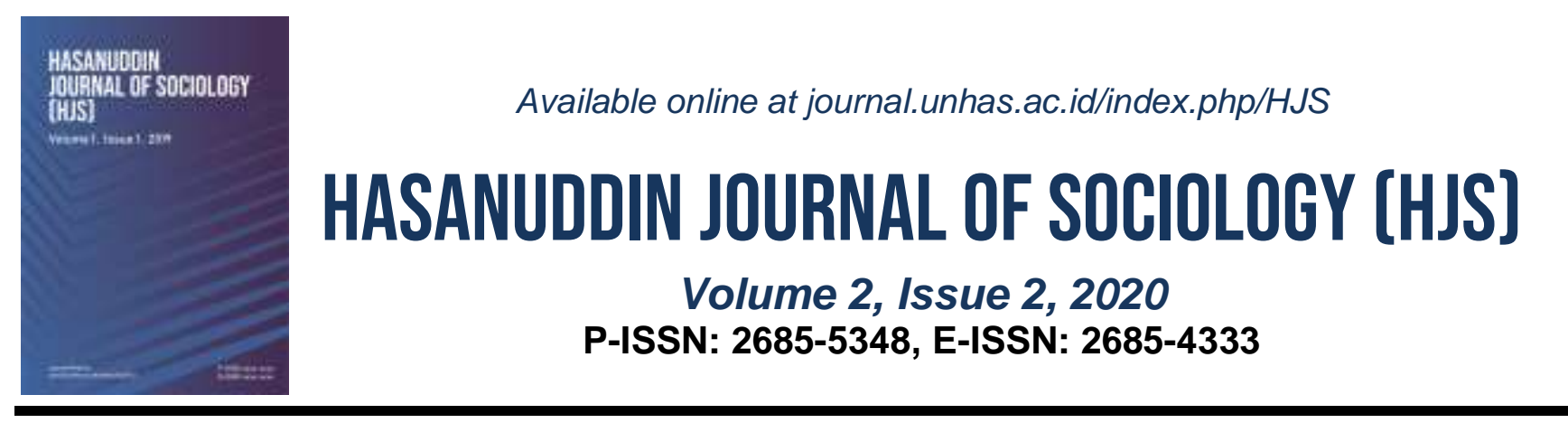

\title{
STRATEGI PENYELESAIAN KONFLIK DALAM KELUARGA DI MASA PANDEMI COVID-19
}

\section{CONFLICT RESOLUTION STRATEGIES IN FAMILIES DURING THE COVID-19 PANDEMIC}

\author{
Anggi Yus Susilowati ${ }^{1}$; Andi Susanto ${ }^{2 *}$ \\ ${ }^{1}$ Jurusan Pengembangan Masyarakat Islam IAIN Syekh Nurjati Cirebon; ${ }^{2}$ Alumni STMIK AKBA \\ Makassar
}

Email Coresponden: ${ }^{1}$ anggiyuss@ syekhnurjati.ac.id; ${ }^{2}$ andisusanto15@mhs.akba.ac.id

\begin{tabular}{l} 
ARTCILE INFO \\
\hline How to Cite: \\
Susilowati, A. Y., \& Susanto, \\
A. (2020). Strategi \\
Penyelesaian Konflik dalam \\
Keluarga di Masa Pandemi \\
Covid-19. Hasanuddin \\
Journal of Sociology (HJS), \\
2(2), 88-97. \\
\\
Keywords: \\
Conflict, Family, Conflict \\
Resolution, Pandemic \\
Kata Kunci : \\
Konflik, Keluarga, Resolusi \\
Konflik, Pandemi.
\end{tabular}

\begin{abstract}
ABSTRACK
The purpose of this research is to study the appropriate conflict resolution strategies in resolving family conflicts during the pandemic. The research method used in this research is library research method. The results of the study show that conflicts within the family during the pandemic, when viewed from the conflicting parties, include conflict between husband and wife, conflict between parents and children, and conflict between siblings. The cause of the family conflict is due to two factors, namely originating from personality problems and other family problems such as family finances or economics, household chores, childcare problems, and interaction problems within the family. Family conflict resolution strategies can be carried out in two methods, namely self-resolving conflict resolution using several approaches that can be used such as collaboration or compromise approaches, defeating opponents or competitions, and avoiding. Conflict resolution methods in resolving family conflicts can also be done with third party interventions to help resolve conflicts that occur.
\end{abstract}

ABSTRAK
Tujuan dari penelitian ini yakni untuk mengkaji strategi
penyelesaian konflik yang tepat dalam menyelesaikan konflik
keluarga dimasa pandemi. Metode penelitian yang digunakan
dalam penelitian ini adalah metode penelitian kepustakaan.
Hasil dari penelitian menunjukan bahwa konflik di dalam
keluarga pada masa pandemi jika dilihat dari pihak yang
berkonflik meliputi konflik pasangan suami istri, konflik antara
orang tua dan anak, serta konflik antarsaudara. Penyebab
terjadinya Konflik keluarga tersebut dikarenakan atas dua
faktor yakni bersumber dari masalah kepribadian dan
bersumber dari masalah keluarga lainnya seperti keuangan atau
ekonomi keluarga, masalah pekerjaan rumah tangga, masalah




pengasuhan anak, serta masalah interaksi di dalam keluarga.
Strategi penyelesaian konflik keluarga dapat dilakukan dengan
dua metode yakni resolusi konflik penyelesaian sendiri dengan
menggunakan beberapa pendekatan yang dapat digunakan seperti
pendekatan kolaborasi atau kompromi, mengalahkan lawan atau
kompetisi, serta menghindar. Metode resolusi konflik dalam
penyelesaian konflik keluarga juga dapat dilakukan dengan
intervensi pihak ketiga untuk membantu menyelesaikan konflik
yang terjadi.

\section{PENDAHULUAN}

Salah satu diantara kebahagiaan yang tidak ternilai materi adalah kebahagiaan hidup dalam keluarga yang Sakinah. Keluarga Sakinah terdiri atas dua suku kata yakni keluarga dan Sakinah. Keluarga adalah suatu unit sosial terkecil dari masyarakat yang didalamnya terdiri dari ayah, ibu, serta anak yang saling berhubungan dan mempengaruhi satu sama lain yang pada akhirnya melahirkan bentuk-bentuk interaksi sosial antar sesama anggota keluarga (ulfiah, 2016: 3). Sedangkan Sakinah secara etimologi atau harfiah diartikan sebagai ketenangan, ketentraman, dan kedamaian jiwa. Jadi keluarga Sakinah adalah merujuk pada keluarga yang harmonis, tenang, tentram, damai dan penuh kasih sayang.

Perjalanan dalam sebuah keluarga pasti akan mengalami pasang surut dalam menjalani kehidupan. Tidak dipungkiri dalam kehidupan berkeluarga pasti pernah mengalami konflik. Konflik dalam kehidupan keluarga merupakan suatu permasalahan yang alamiah. Konflik itu pasti ada dan terjadi dikehidupan sehari-hari. baik disadari maupun tidak.

Melihat pada kondisi kehidupan sekarang ini yang mana sedang dilanda wabah pandemi covid-19, tidak dipungkiri pasti berdampak pula pada kehidupan keluarga. seperti kita lihat dan dengar banyak sekali pemberitaan di Televisi tentang permasalahan keluarga seperti pembunuhan, kekerasan dalam rumah tangga (KDRT), perselingkuhan, hingga yang sedang gempar seperti meningkatnya angka jumlah perceraian dalam rumah tangga diberbagai daerah di Indonesia. Seperti pemberitaan disalah satu statiun televisi yang diupload ke Youtube dengan akun Apa Kabar Indonesia tvOne yang mana telah memberitakan tentang meningkatnya angka perceraian di Bandung dan Yogyakarta di Tengah Pandemi yang diakibatkan karena permasalahan dalam keluarga seperti masalah ekonomi di masa pandemi tersebut.

Berdasarkan dari penggambaran diatas, maka penelitian ini mencoba untuk mengkaji bagaimana strategi dari penyelesaian konflik dalam keluarga di masa pandemi. Dalam penelitian ini juga sangat penting menganalisis jenis konflik dan faktor-faktor yang mempengaruhi terjadinya konflik tersebut sehingga dapat merumuskan strategi yang tepat untuk penyelesaian konflik keluarga. 


\section{METODE PENELITIAN}

Penelitian ini menggunakan metode penelitian kepustakaan (library research) yaitu penelitian yang kajiannya dilakukan dengan menelusuri dan menelaah literatur yang relevan dengan topik yang menjadi objek penelitian. Sumber data dalam penelitian ini diperoleh dari berbagai karya tulis seperti buku, makalah, internet, artikel, skripsi, tesis, disertasi dan sumbersumber lainnya yang ada hubungannya dengan masalah yang diteliti. Dalam penelitian kepustakaan ini, pengumpulan data baik primer maupun sekunder dilakukan peneliti dengan pengumpulan data non-lapangan, oleh karena itu peneliti dapat memanfaatkan semua informasi dan pemikiran yang relevan dengan objek penelitian yang dilakukan (Prastowo, 2016: 191).

Teknik analisis data dalam penelitian ini menggunakan metoda analisis isi (Content Analysis), yaitu teknik analisis dengan cara memilih, membandingkan, mengabungkan dan memilah berbagai pengertian sehingga ditemukan data yang relevan dan mendasar untuk dijadikan langkah dalam pengambilan kesimpulan (Moleong, 2006: 289).

\section{HASIL PENELITIAN DAN PEMBAHASAN}

\subsection{Konflik yang terjadi dalam keluarga}

Berdasarkan Kamus Besar Bahasa Indonesia konflik berarti percekcokan, perselisihan dan pertentangan. Dari definisi tersebut menunjukkan bahwa konflik sebagai suatu kondisi atau keadaan dimana terjadi sebuah peristiwa yaitu percekcokan, perselisihan atau pertentangan.

Menurut Puspita (2018: 5) konflik dapat diartikan sebagai peristiwa positif maupun peristiwa negatif tergantung pada sudut pandang seseorang. Pada pengertian positif, definisi konflik adalah suatu keadaan terjadinya perselisihan atau pertentangan antara dua orang atau kelompok untuk mencapai tujuan yang lebih baik dari orang lain, dan diantara keduanya tidak ada perasaan terganggu. Berbeda dari itu, definisi konflik dalam pengertian negatif adalah suatu perbuatan saling berselisih antara dua orang atau lebih yang berjuang untuk menang atau kalah.

Dalam kehidupan berkeluarga pertengkaran atau konflik tidak dapat dihindarkan. Adapun konflik-konflik yang terjadi dalam keluarga dapat ditinjau dari subjek atau pihak yang berkonflik di dalam keluarga, seperti;

1. Konflik pasangan suami istri

Dalam hubungan suami istri, pasti selalu menginginkan memilki kehidupan rumah rumah tangga yang tenang dan damai. Untuk itu setiap pasangan suami istri senantiasa perlu saling menciptakan hubungan yang harmonis diantara keduanya. Namun dalam hubungan berumah tangga pasti terjadi konflik antara suami dan istri. Konflik tersebut bukanlah hal yang harus dihindari oleh pasangan suami istri melainkan harus dihadapi dan diselesaikan.

2. Konflik orang tua dengan anak 
Secara naluriah, orang tua akan menganggap anaknya sebagai bagian paling penting dalam hidupnya. Dalam posisi tersebut orang tua akan berusaha mencapai kebahagiaan dan kesejahteraan anak. Dengan persepektif demikian, seharusnya konflik orang tua dan anak tidak akan terjadi karana orang tua akan senantiasa berkorban untuk anaknya. Namun realitanya hubungan orang tua anak sering kali mengandung perspektif kekuasaan dan kewenangan. Selain terdapat aspek ketanggapan dalam merespon kebutuhan anak, terdapat juga aspek tuntutan yang mencerminkan harapan orang tua terhadap sikap dan perilaku anak. Dampaknya hubungan orang tua dan anak diwarnai dengan berbagai konflik (ulfiah, 2016: 86).

3. Konflik antarsaudara

Lestari dalam Ulfiah (2016: 35-36) mengemukakan hubungan antar saudara dapat mempengaruhi perkembangan individu baik secara positif maupun negatif tergantung pada pola hubungan yang terjadi. Cara orang tua memperlakukan anak satu dengan yang lain juga mempengaruhi hubungan antar saudara. Perbedaan perlakuan dapat menimbulkan kecemburuan gaya kelekatan dan harga diri dan pada waktunya dapat menimbulkan distres pada hubungan romantis di kemudian waktu. Konflik antar saudara juga dapat dipengaruhi karena kekuatan emosi, keintiman dan perbedaan sifat pribadi.

Dimasa pandemi ini, konflik jika tidak ditangani segera dengan baik dapat berujung pada kekerasan. Kekerasaan merupakan suatu tindakan yang dilakukan oleh seseorang kepada orang lain baik secara fisik maupun non fisik. Secara Etimologi, kata kekerasan berasal dari Bahasa Inggris yaitu violence dan dari Bahasa Latin yaitu violentus. keduanya berasal dari kata vi atau vis yang berarti kekuasaan atau berkuasa. Pada prisip dasar hukum publik dan privat romawi kekerasan merupakan sebuah ekspresi baik yang dilakukan secara fisik ataupun secara verbal yang mencerminkan pada tindakan agresi dan penyerangan pada kebebasan atau martabat seseoarang yang dapat dilakukan oleh perorangan atau sekelompok orang tanpa menindahkan keabsahan penggunaan atau tindakan kesewenang-wenangan (Wikipedia).

Dalam kamus besar Bahasa Indonesia kekerasan dapat diartikan sebagai; (1) perihal atau peristiwa yang bersifat keras: (2) kekerasan adalah suatu perbuatan seseorang atau sekelompok orang yang menyebabkan cidera, melukai, atau matinya orang lain; (3) paksaan. Dari pengertian tersebut dapat disimpulkan bahwa kekerasan adalah suatu peristiwa yang dilakukan oleh seseorang atau sekelompok orang dengan paksaan sehingga membuat orang lain cidera, luka, bahkan meninggal.

Dimasa pandemi ini, konflik bisa saja menimbulkan terjadinya kekerasan di dalam keluarga. Kekerasan tersebut dapat meliputi;

1. Kekerasaan Fisik

Kekerasan fisik adalah tindakan yang benar-benar merupakan gerakan fisik untuk menyakiti tubuh atau merusak harta orang lain. Kekerasaan fisik dapat menyebabkan korban babak belur 
atau harta yang sudah lenyap dijarah (Hendarti dan Herudjati Purwoko; 2008). Kekerasan fisik di dalam keluarga dapat berupa perlakuan seperti memukul, manampar, mencekik, menginjak, melukai baik dengan tangan kosong atau dengan senjata, menganiaya, menyiksa, dan membunuh.

\section{Kekerasan Verbal}

Tanpa disadari sesungguhnya kekerasan verbal sering terjadi di dalam keluarga. Kekerasan verbal merupakan kekerasan terhadap perasaan menggunakan kata-kata dengan kata-kata yang kasar tanpa menyentuh fisiknya. Kata-kata yang memfitnah, kata-kata yang mengancam, menakutkan, menghina, atau membesar-besarkan kesalahan orang lain (Sutikno dalam Putri: 2012).

Dari definisi tersebut, kekerasan verbal dalam keluarga dapat berupa ancaman, perkataan kasar, celaan, makian, ejekan, fitnah, menyalahkan, memberi label, dan menghina dan melecehkan secara terus menerus yang berpotensi mengakibatkan luka psikologis, trauma, dan perasaan rendah diri.

3. Kekerasan Simbolik

Kekerasaan simbolik merupakan tindakan yang memanfaatkan berbagai media atau sarana untuk menyakiti hati atau merugikan kepentingan orang lain. Menurut Ulya (2016), kekerasaan simbolik adalah kekerasaan yang beroperasi dibawah ketidaksadaran pelaku maupun korbannya sehingga bersifat nirsadar dan laten sebagai akibat langsung dari adanya perbedaan pemisahan ketidaksamaan, ketidaksetaraan, atau ketidakseimbangan atau distingsi (distinction) dalam setiap hubungan dalam keluarga.

Kekerasan simbolik dalam keluarga dapat berupa perilaku menekan dengan perintah dan larangan yang bertujuan untuk mengarahkan dan mengontrol tindakan ke titik tertentu tanpa memberi kelonggaran untuk memilih. Dampak dari kekerasan simbolik ialah terjadi ketidakstabilan kejiwaan. Oleh karena itu kekerasan simbolik perlu diwaspadai karena kekerasan ini dapat menjadi awal munculnya kekerasan verbal atau bahkan dapat menyebabkan terjadinya kekerasan fisik.

Menurut Pasal 5 UU PKDRT No. 23 Tahun 2004, dinyatakan bahwa bentuk-bentuk kekerasan dalam keluarga atau yang lebih kenal dengan KDRT (kekerasan dalam rumah tangga) adalah sebagai berikut;

a. Kekerasaan fisik, yaitu perbuatan yang mengakibatkan rasa sakit, jatuh sakit atau luka berat.

b. Kekerasan psikis, yaitu perbuatan yang mengakibatkan ketakutan, hilangnya rasa percaya diri, hilangnya kemampuan untuk bertindak, rasa tidak berdaya, dan/atau penderitaan psikis berat pada seseorang.

c. Kekerasan seksual, yaitu pemaksaan hubungan seksual yang dilakukan terhadap orang dalam lingkup rumah tangga atau keluarga tersebut. 
d. Penelantaran rumah tangga, yaitu perbuatan yang mengakibatkan ketergantungan ekonomi dengan cara membatasi dan/atau melarang orang bekerja yang layak di dalam atau di luar rumah sehingga korban berada di bawah kendali orang tersebut. (Nisa, 2018).

\subsection{Penyebab terjadinya konflik keluarga}

Secara umum konflik di dalam keluarga dapat terjadi dikarenakan adanya masalah atau faktor-faktor tertentu. Persoalan-persoalan tersebut dapat dikatakan menjadi penyebab atau sumber terjadinya konflik keluarga. Adapun faktor-faktor penyebab terjadinya konflik keluarga yakni seperti;

1. Konflik keluarga yang bersumber dari kepribadian.

Menurut Hadisubrata (2003), konflik dalam keluarga khususnya konflik hubungan suamiistri biasanya bersumber pada kepribadian suami istri seperti;

a. Ketidakmatangan kepribadian

Sumber konflik dalam keluarga dapat disebabkan karena ketidakmatangan kepribadian dari salah satu atau kedua pasangan suami-istri di dalam keluarga. Ketidakmatangan kepribadian tersebut seperti tidak atau belum sadar atas tanggung jawab, masih suka ikut-ikutan atau tidak punya prinsip, suka memburu kesenangan sendiri tanpa memikirkan pasangan.

b. Adanya sifat-sifat kepribadian yang tidak cocok

Adanya sifat-sifat kepribadian yang tidak cocok untuk menjalin hubungan di dalam keluarga dapat menjadi sumber terjadinya konflik keluarga seperti sifat egois, keras kepala, selalu curiga atau kurang percaya, mudah tersinggung, berusaha membenarkan diri atau menutupi kesalahan, dan lain sebagainya. Apabila sifat-sifat ini ada di dalam kehidupan keluarga maka akan menjadi penyebab terjadinya konflik keluarga bahkan memicu terjadinya kekerasaan.

c. Adanya kelainan mental

Ada beberapa hal kelainan mental yang dapat memicu konflik dalam keluarga seperti perilaku abnormal, kelainan seks (homoseks/lesbian), psikosis dan lain sebagainya.

2. Konflik keluarga yang bersumber dari masalah-masalah yang erat kaitannya dengan keluarga, antara lain;

a. Keuangan atau ekonomi

Masalah ekonomi atau keuangan merupakan masalah rumah tangga yang sering dialami keluarga baik pada pasangan yang baru menikah maupun yang berumah tangga lama. Kesulitan hidup dalam keluarga yang dihadapi sering berkaitan deangan masalah ekonomi keluarga. masalah tersebut tidak boleh dianggap enteng atau dibiarkan begitu saja tanpa ada upaya dan solusi untuk masalah ekonomi atau keuangan keluarga ini sangat rentang dan dapat menjadi sumber permasalahan atau konflik seperti percekcokan hingga rusaknya hubungan dalam rumah tangga. 
Dimasa pandemi ini banyak keluarga yang mengalami masalah ekonomi atau keuangan seperti penghasilan yang menurun atau kehilangan pekerjaan.

b. Pekerjaan rumah tangga

Dimasa pandemi, banyak keluarga baik suami atau istri (sebagai orang tua pekerja) harus bekerja dari atau di rumah. Jika sebelum pandemi pekerjaan kantor diselesaikan di kantor, kali ini pekerjaan kantor harus diselesaikan di rumah. Tidak dipungkiri bahwa selain harus menyelesaikan pekerjaan kantor sering juga harus atau diselingi dengan pekerjaan atau tugas-tugas rumah tangga lainnya. Oleh karena itu perlu adanya pembagian tugas bersama untuk pekerjaan rumah tangga dalam keluarga dengan baik, karena jika tidak adanya pembagian tugas kerja rumah tangga dapat memicu terjadinya konflik-konflik di dalam keluarga.

c. Pengasuhan anak

Selain pembagian tugas rumah tangga dalam keluarga, pengasuhan anak juga dapat menjadi sumber atau faktor yang menimbulkan terjadinya konflik keluarga. Oleh karena itu tugas pengasuhan anak perlu menjadi tugas bersama antara suami istri di dalam keluarga. Pengasuhan anak tidak hanya terfokus pada peran menjaga anak saja melainkan juga menjaga kesehatan anak, mendidik anak agar tumbuh dan berkembang dengan baik secara fisik maupun mental, serta menjaga kebahagiaan anak-anak dengan perhatian dan kasih sayang.

d. Interaksi di dalam keluarga

Komunikasi adalah sarana untuk mengutarakan keinginan, keluhan, kebutuhan atau persoalan-persoalan yang dihadapi anggota keluarga. Kurangnya komunikasi atau interaksi dengan anggota keluarga dengan intens atau baik dapat menjadi sumber terjadinya konflik. Hal ini dikarenakan, komunikasi atau interaksi dengan intensitas yang tinggi di dalam keluarga akan berdampak pada semakin tingginya kesempatan untuk berbagi dan saling mendukung dan menciptakan kedekatan satu sama lain anggota keluarga (Ermawati, 2016: 65)

\subsection{Strategi Penyelesaian konflik keluarga}

Suatu konflik keluarga yang sedang terjadi dapat berdampak positif maupun negatif tergantung dari cara, sikap, dan pola pikir dalam mengelolanya. Konflik keluarga bagaimanapun bentuknya harus dihadapi, diselesaikan dan dicari solusinya. Konflik keluarga yang bersifat negatif jika tidak segera di atasi dapat menyebabkan situasi atau hubungan keluarga semakin memburuk, oleh karena itu perlu dilakukan strategi-strategi dalam menyelesaikan konflik tersebut yakni dengan pendekatan resolusi konflik.

Resolusi konflik yang dalam Bahasa inggris yakni conflict resolution memiliki pengertian yang berbeda-beda menurut beberapa para ahli yang fokus meneliti tentang konflik. Resolusi 
konflik adalah suatu usaha untuk menangani sebab-sebab konflik serta berusaha untuk membangun hubungan baru yang dapat bertahan lama di dalam kelompok-kelompok yang mengalami konflik (Fisher, dalam Haryati, 2017: 836). Sedangkan menurut Weitzman dalam Morton and Coleman, mendefinisikan resolusi konflik sebagai sebuah tindakan pemecahan masalah bersama (solve a problem together). Dari kedua definisi tersebut dapat disimpulkan bahwa resolusi konflik merupakan suatu cara atau proses yang dilakukan pihak-pihak yang berkonflik dalam menyelesaian masalah yang sedang dihadapi.

Menurut Wirawan (2016: 177), metode resolusi konflik dapat dikelompokkan dalam dua strategi yakni pengaturan sendiri oleh pihak-pihak yang terlibat konflik (self-regulation) atau melalui intervensi pihak ketiga (third party intervention). Resolusi konflik dengan pengaturan sendiri dapat dilakukan jika kedua pihak yang berkonflik ingin berupaya menyelesaikan sendiri konfliknya. Pihak-pihak yang terlibat konflik saling melakukan pendekatan atau negosiasi dalam menyelesaikan konflik untuk mendapatkan keluaran konflik sesuai dengan yang diharapkan. Adapun pendekatan yang dapat dilakukan dalam metode pengaturan sendiri yaitu pendekatan kolaborasi atau kompromi, pendekatan mengalahkan lawan, dan pendekatan menghindar. Untuk menyelesaikan sebuah konflik tidak terpaku pada satu pendekatan saja melainkan bisa dengan menggabungkan beberapa pendekatan, hal ini di sesuaikan dengan situasi konflik sesuai dengan tujuan yang diharapkan.

Metode resolusi konflik yang dapat digunakan untuk menyelesaikan konflik dapat juga dengan melibatkan pihak ketiga. Metode ini sering digunakan ketika pihak-pihak yang terlibat konflik tidak mampu menyelesaikan konflik yang dialami atau tidak mau mengalah. Intervensi pihak ketiga sering kali lebih bermanfaat jika kedua belah pihak tidak mampu menyelesaikan konflik mereka, pihak ketiga bisa bersikap pasif dengan menunggu pihak yang terlibat konflik meminta bantuan, atau dapat bertindak aktif dengan membujuk kedua belah pihak untuk menyelesasikan konflik.

Penyelesaian konflik dalam keluarga dalam masa pandemi dapat dilakukan dengan metode resolusi konflik pengaturan sendiri atau dapat juga dengan resolusi konflik intervensi pihak ketiga. Strategi penyelesaian konflik dalam keluarga tersebut tergantung dari jenis konflik dan sumber atau penyebab konflik keluarga. Strategi resolusi konflik keluarga dapat dibedakan menjadi deskruktif dan konstruktif. Dua hal yang sering kali membuat resolusi konflik keluarga tidak efektif adalah tindakan menyalahkan orang dan mengungkit persoalan yang telah lalu. Resolusi konflik keluarga yang konstruktif dapat dilakukan dengan menentukan pokok permasalahan, mendiskusikan sumbangan masing-masing pada permasalahan yang muncul, mendiskusikan jalan keluar untuk menyelesaikan masalah, dan menentukan serta menghargai peran masing-masing terhadap penyelesaian masalah. 


\section{KESIMPULAN}

Dari hasil penelitian dapat penulis simpulkan bahwa konflik yang terjadi di dalam keluarga dimasa pandemi dapat dilihat dari sudut pihak yang berkonflik yakni konflik pasangan suami istri, konflik orang tua dengan anak, dan konflik antarsaudara. Konflik-konflik tersebut jika tidak segera diselesaikan dapat berpotensi menimbulkan terjadinya kekerasan di dalam keluarga baik kekerasan fisik, kekerasan verbal maupun kekerasan simbolik. Faktor penyebab terjadinya konflik dan kekerasan dalam keluarga dapat bersumber dari masalah kepribadian dan masalah lain dalam keluarga seperti masalah ekonomi atau keuangan, masalah pekerjaan rumah tangga, masalah pengasuhan anak, serta masalah interaksi di dalam keluarga. Untuk meminimalisir atau menghidari terjadinya konflik dan kekerasan di dalam keluarga di masa pandemi maka perlu dilakukan penyelesaian konflik dengan pendekatan atau strategi yang tepat sesuai dengan jenis dan sumber konflik. Ada 2 resolusi konflik yang dapat digunakan untuk menyelesaiakan konflik yang terjadi di dalam keluarga yakni dengan pengaturan sendiri (self-regulation) dan melibatkan pihak ketiga (intervensi pihak ketiga).

\section{DAFTAR PUSTAKA}

Ermawati, Siti. (2016). Peran Ganda Wanita Karier (Konflik Peran Ganda Wanita Karier di tinjau dalam Perspektif Islam). Jurnal Edutama. Vol. 2, No. 2.

Hadisubrata, M.S. (2003). Keluarga dalam Dunia Modern, Tantangan dan Pembinaannya. Jakarta: BPK Gunung Mulia.

Haryati. (2017). Penyesuaian pernikahan dan Model Resolusi Konflik pada Menantu Perempuan yang Tinggal Serumah dengan Mertua. Jurnal Psikoborneo. Vol. 5, No.4, 2017: 833-843.

Hendrarti, Hendrarti dan Herudjati Purwoko. (2008). Aneka Sifat Kekerasan Fisik, Simbolik, Birokratik \& Struktural. Cet. Pertama. Jakarta: PT Indeks.

Moleong, Lexy. (2006). Metodologi Penelitian Kualitatif. Bandung: PT. Rosydakarya Putra.

Nisa, Haiyun. (2018). Gambaran Bentuk Kekerasaan dalam Rumah Tangga yang Dialami Perempuan Penyitas. Jurnal Gender Equality: Internasional Journal of Child and Gender Studies. Vol. 4. No.2

Prastowo, Andi. (2016). Metoda Penelitian Kulalitatif. Jakarta: Ar-Ruzz Media.

Puspita, Weni. (2018). Manajemen Konflik (Suatu Pendekatan Psikologi, Komunikasi, dan Pendidikan). Yogyakarta: Deepublish.

Putri, Annora Mentari \& Agus Santosa. (2012). Persepsi Orang Tua Tentang Kekerasan Verbal pada Anak. Jurnal Nursing Studies. Vol. 1 No. 1 
Tim PrimaPena. Kamus Besar Bahasa Indonesia. Gitamedia Press.

Ulfiah. (2016). Psikologi Keluarga: Pemahaman hakekat Keluarga dan Penanganan Problematika Rumah Tangga. Bogor: Ghalia Indonesia.

Ulya. (2016). Mewaspadai Kekerasan Simbolik dalam Relasi Orang Tua dan Anak. Jurnal Palastren. Vol. 9, No. 2.

Wikipedia Diakses melalui https://id.wikipedia.org/wiki/Kekerasan pada tanggal 2 Oktober 2020

Youtube oleh akun Apa Kabar Indonesia tvOne. Waduh! Perceraian di Bandung dan Yogyakarta Meningkat di Tengah Pandemi. Diupload pada 25 Agustus 2020. https://www.youtube.com/watch?v=lDXHBFBDf-o 
